NBER WORKING PAPER SERIES

THE MISSING BRETTON WOODS DEBATE OVER FLEXIBLE EXCHANGE RATES

\author{
Douglas A. Irwin \\ Working Paper 23037 \\ http://www.nber.org/papers/w23037 \\ NATIONAL BUREAU OF ECONOMIC RESEARCH \\ 1050 Massachusetts Avenue \\ Cambridge, MA 02138 \\ January 2017
}

This paper was prepared for the Yale conference on Bretton Woods, November 5-6, 2015. I am grateful to Michael Bordo, Eric Helleiner, and other participants for helpful feedback. The views expressed herein are those of the author and do not necessarily reflect the views of the National Bureau of Economic Research.

NBER working papers are circulated for discussion and comment purposes. They have not been peer-reviewed or been subject to the review by the NBER Board of Directors that accompanies official NBER publications.

(C) 2017 by Douglas A. Irwin. All rights reserved. Short sections of text, not to exceed two paragraphs, may be quoted without explicit permission provided that full credit, including ()$^{\circ}$ notice, is given to the source. 
The Missing Bretton Woods Debate over Flexible Exchange Rates

Douglas A. Irwin

NBER Working Paper No. 23037

January 2017

JEL No. B22,F31,F33

\begin{abstract}
$\underline{\text { ABSTRACT }}$
The collapse of the gold standard in the 1930s sparked a debate about the merits of fixed versus floating exchange rates. Yet the debate quickly vanished: there was almost no discussion about the exchange rate regime at the Bretton Woods conference in 1944 because John Maynard Keynes and Harry Dexter White agreed that exchange rate stability through fixed but adjustable pegs was the right approach. In light of the difficult macroeconomic tradeoffs experienced under the gold standard a decade earlier, the outright rejection of floating exchange rates seems surprising. This paper explores the views of leading economists about the exchange rate provisions in the Bretton Woods agreement and examines why arguments for floating exchange rates were so quickly dismissed.
\end{abstract}

Douglas A. Irwin

Department of Economics

Dartmouth College

Hanover, NH 03755

and NBER

douglas.irwin@dartmouth.edu 


\section{The Missing Bretton Woods Debate over Flexible Exchange Rates ${ }^{1}$}

\section{Introduction}

In his Tract on Monetary Reform, John Maynard Keynes (1923) argued that a country's central bank could stabilize the domestic price level or fix the exchange rate, but not necessarily do both at the same time. While the two objectives were compatible in some circumstances, a country would have to choose one over the other if they were incompatible. The potential conflict between internal and external policy objectives was forcefully demonstrated in the Great Depression of the early 1930s. Countries could either maintain fixed exchange rates by staying on the gold standard and enduring a painful deflation, or they could maintain stable prices by leaving the gold standard and allowing their currencies to depreciate. One by one countries opted for domestic price stability over exchange rate stability. By 1936 no major country was on the gold standard.

The collapse of the gold standard sparked a debate over international monetary arrangements that culminated in the Bretton Woods conference in 1944. Given the disastrous experience of the 1930s, one might have thought that economists and government officials would have considered a system of flexible exchange rates that would allow central banks to focus on domestic economic stability and full employment. In fact, there was very little debate about the postwar exchange rate system and virtually none at the Bretton Woods conference itself. While there was no interest in returning to the gold standard or having rigidly fixed exchange rates, there was also no discussion of adopting floating exchange rates. Instead, most economists advocated, and the participants at Bretton Woods endorsed, the halfway house of "fixed but

\footnotetext{
${ }^{1}$ Prepared for the Yale conference on Bretton Woods, November 5-6, 2015. I am grateful to Michael Bordo, Eric Helleiner, and other participants for helpful feedback.
} 
adjustable" exchange rates. Exchange rate stability was desired, but it was also recognized that rates would have to be changed occasionally in the case of "fundamental disequilibrium."

Why were flexible exchange rates not seriously considered in the debate over the postwar international monetary system? Flexible exchange rates were dismissed because they were equated with monetary instability and trade protectionism. For most economists, the main lesson taken from the 1930s was not just that the gold standard had failed, but that flexible exchange rates had failed too. That was the view of Ragnar Nurkse, whose influential International Currency Experience was published by the League of Nations in 1944. According to Nurkse (1944, 137): "If there is anything that interwar experience has clearly demonstrated, it is that paper currency exchanges cannot be left free to fluctuate from day to day under the influence of market supply and demand" because speculation would "play havoc" with them. The professional consensus among economists ran against flexible exchange rates at least until Milton Friedman published his famous essay "The Case for Flexible Exchange Rates" in 1953.

This paper examines why the case for floating exchange rates was not taken seriously in the discussions about the international monetary system in the late 1930s and 1940s. After looking at the debate about the exchange rate regime after the collapse of the gold standard, we then turn to the reaction of economists to the Keynes and White plans that formed the basis for the Bretton Woods agreement. Finally, we look at the early post-war discussion of exchange rates after the International Monetary Fund (IMF) had been established and the Bretton Woods system was in place.

\section{Lessons from the Gold Standard Collapse}

In his 1923 book, Keynes argued that countries - specifically, their central banks - faced a dilemma in choosing between internal objectives (stable domestic prices) and external 
objectives (stable exchange rates). If a country chose external stability through a fixed exchange rate, it would give up control over internal prices; if it chose to stabilize internal prices, it might have to sacrifice stable exchange rates. Because the late nineteenth century gold standard was unique in delivering both external and internal stability, Keynes $(1923,158)$ noted, "the choice between stable exchanges and stable prices had not presented itself as an acute dilemma." But if there were "violent shocks" to the world price level, the gold standard "is likely to break down in practice" because internal prices could not adjust quickly enough to avoid a painful adjustment to domestic production and employment. Therefore, he concluded, "when stability of the internal price level and stability of the external exchanges are incompatible, the former is generally preferable; and that on occasions when the dilemma is acute, the preservation of the former at the expense of the latter is, fortunately perhaps, the line of least resistance."

Following this logic, Keynes $(1923,172)$ rejected a return to the gold standard after World War I because that would allow "the tides of gold to play what tricks they like with the internal price level," preventing governments from ensuring stable prices and full employment. Keynes also rejected a central-bank managed gold standard "in the pious hope that international co-operation will keep it in order.” At the same time, Keynes rejected an exclusive focus on domestic price stability, doubting "the wisdom and the practicability of a system so cut and dry" as Irving Fisher's compensated dollar scheme.

Instead, Keynes $(1923,186)$ recommended a blended system: "my scheme would require that they [the Bank of England] should adopt the stability of sterling prices as their primary objective - though this would not prevent their aiming at exchange stability also as a secondary objective by co-operating with the Federal Reserve Board in a common policy." Such a policy, Keynes $(1923,190)$ wrote, would ensure that exchange rates "would not move with every breath 
of wind but only when the Bank had come to a considered judgement that a change was required for the sake of stability of sterling prices."

Though writing in 1923, Keynes was prophetic about the potential problems with the interwar gold standard and the possible conflict between internal and external policy objectives. ${ }^{2}$ When the managed gold standard started to malfunction around 1929 and countries began to experience deflation, they began to abandon the gold standard, opting for stable domestic prices rather than stable exchange rates, just as Keynes suggested. ${ }^{3}$ However, rather than simply choosing between staying with a fixed exchange rate under the gold standard or letting the exchange rate go to maintain internal price stability, some countries opted to impose exchange and capital controls in an effort to have both a fixed exchange rate and monetary independence. Thus, Keynes's policy dilemma became a policy trilemma. Countries had to choose two of three policies: a fixed exchange rate, an independent monetary policy, and a convertible currency free from exchange controls. ${ }^{4}$ Different countries with different historical experiences chose different paths, but the gold standard ceased to exist by 1936.

As is now well known, the countries that left the gold standard were able to pursue more expansionary monetary policies that helped stimulate economic recovery; the countries that prolonged their stay on the gold standard continued to suffer through the slump. ${ }^{5}$ This lesson was recognized by international organizations at the time. In 1936, the League of Nations reported

\footnotetext{
${ }^{2}$ Bordo and Schwartz (1996) show how conflicts between internal and external stability have led to numerous currency crises throughout history.

${ }^{3}$ The desire of central banks to accumulate gold reserves contributed to a worldwide shortage of gold and strong deflationary pressure starting in 1929; see Eichengreen (1992), Johnson (1997), Irwin (2013), Mazumder and Wood (2013), and Sumner (2015). A large literature seeks to explain the reasons for the timing of a country's exit from the gold standard; see Wandschnider (2008), Wolf (2008), and Wolf (2011).

${ }^{4}$ Obstfeld, Shambaugh, and Taylor 2004; Irwin 2013.

${ }^{5}$ Eichengreen (1992) is a classic reference. The countries that imposed exchange controls had some scope for monetary expansion but failed to use it (Mitchner and Wandschneider 2015).
} 
that the turning point from depression to recovery in every country was "characterized by an increase in the supply of money" and that "in those few countries which did not either depreciate their currency or use the protection afforded by exchange control to pursue an expansionist monetary policy, no considerable measure of economic improvement had taken place by the end of 1935." Similarly, the International Labour Office concluded in 1937 that "one of the clearest teachings of the depression is that the maintenance of the domestic equilibrium must be the primary objective of monetary policy, even if it entails lowering the external value of the currency." "If the depression has shown one thing more clearly than anything else it is that economic prosperity and social security depend more on monetary policy than on any other single factor," the ILO continued. "The demonstration that in one country after another the upturn in business and employment coincided not with the reduction of wage-rates, the cutting of costs or the deterioration of working conditions but with the abandonment of deflation and the adoption of monetary expansion has made a deep impression on the world." 6

\section{What Comes after Gold?}

Yet apparently the impression was not all that deep because, in the wake of the gold standard's collapse, most policymakers and economists wanted a quick return to exchange rate stability rather than continuing with monetary policies that would provide stability and growth. Policymakers in the United States, Britain, and France reached the Tripartite Agreement in 1936 to restore relatively fixed exchange rates. Most economists were deeply suspicious of leaving exchange rates to be determined by the market. This suspicion came from the received view of historical experience. The two recent periods of floating exchange rates had been in the early 1920s, before most countries had returned to the gold standard, and in the mid-1930s, after

\footnotetext{
${ }^{6}$ For these quotes, see Lester $(1939,297-98)$.
} 
Britain and others abandoned the gold standard. The first period was marked by monetary instability and hyperinflation in Germany and elsewhere and wide exchange rate fluctuations that were attributed to destabilizing speculative capital flows. The second period was described as a period of "competitive devaluations" which were thought to constitute "beggar thy neighbor" policies and result in protectionist trade policies. ${ }^{7}$

Keynes managed to negotiate all of these considerations in proposing a way forward. In the General Theory of Employment, Interest and Money (1936, 270), Keynes argued against permanently fixed exchange rates as a "most dangerous" threat to the use of monetary policy (interpreted as changes in domestic interest rates) to maintain full employment. As he stated: "I am now of the opinion that the maintenance of a stable general level of money-wages is, on the balance of considerations, the most advisable policy for a closed [economic] system; whilst the same conclusion will hold good for an open [economic] system, provided that equilibrium with the rest of the world can be secured by means of fluctuating exchanges."

Keynes seemed to be proposing that each country would pursue its own independent monetary policy based on its own domestic economic conditions with exchange rates left free to adjust. And yet he never actually embraced flexible exchange rates. When someone inquired about his position on exchange rates shortly after the publication of the General Theory, Keynes $(1980,501)$ stated: "In general I remain in favour of independent national systems with fluctuating exchange rates" but "there need be no reason why the exchange rate should in practice be constantly fluctuating." Instead, he was "entirely in favour of practical measures towards de facto stability so long as there are no fundamental grounds for a different policy." By

\footnotetext{
${ }^{7}$ Cesarano (2006) provides an excellent account of economic thinking during this period.
} 
the late 1930s, Keynes's position could be described as favoring fixed but adjustable exchange rates with exchange controls, just like he had in $1923 .{ }^{8}$

Keynes's preference for some exchange rate flexibility to pursue domestic economic policy objectives was considered heresy by many economists. At the London School of Economics, Friedrich Hayek and Lionel Robbins lamented the loss of security and dependability that came with the demise of the gold standard. They associated fixed exchange rates with stability and certainty and adjustable exchange rates with instability and uncertainty. They disparaged Keynes's “monetary nationalism," which implied managed, fiat currencies, on the grounds that it would bring monetary instability and economic chaos. Instead, they advocated "monetary internationalism" in which multilateral cooperation would permit a return to some type of gold standard. For example, Hayek $(1937,93)$ believed that "a really rationale monetary policy could be carried out only by an international monetary authority" and would require reestablishing fixed exchange rates. Hayek $(1937,84)$ thought this was "a demand for reforms in exactly the opposite direction from those advocated by Monetary Nationalists. Instead of flexible parities or a widening of the 'gold points,' absolute fixity of the exchange rates should be secured by a system of international par clearance.”

Hayek $(1937,64)$ leveled three main criticisms against flexible exchange rates, all of which were frequently repeated during this period. First, flexible exchange rates would give rise to speculative capital flows that would be destabilizing; specifically, capital movements would reinforce exchange rate shifts arising from payments imbalances, thereby magnifying volatility and "turn what originally might have been a minor inconvenience into a major disturbance." Second, flexible exchange rates would lead to competitive depreciations, the flexible rate

\footnotetext{
${ }^{8}$ As Donald Moggridge (1986, 66-67) points out, "By the time Keynes came to draft his proposals for the post-World War II monetary system, he had at one time or another recommended almost every exchange rate regime known to modern analysts except completely freely floating exchange rates."
} 
counterpart to competitive devaluations, which would encourage a return to mercantilism and an increase in trade barriers. "Without stability of exchange rates it is vain to hope for any reduction of trade barriers," he concluded $(1937,74 n)$. Third, exchange rate instability would create risks that would discourage international trade and deter long-term foreign investment.

Echoing these arguments, Robbins $(1937,290-91)$ held that "of all the forms of economic nationalism, monetary nationalism is the worst" and warned of the "dangers of a regime of free exchanges." Like Hayek, he believed that flexible exchange rates would lead to "cumulative financial chaos" and the disintegration of the world economy. Furthermore, Robbins (1937, 28789) found it "necessary to challenge directly" the assumption that flexible exchange rates will lead to equilibrium adjustments: "For there is no reason to believe that it is in any way justified. On the contrary, both theory and experience suggest that ... the fluctuations of the exchanges have an actively disequilibrating tendency." Without a tendency to reach an equilibrium, the system would result in "just a vicious circle of inflation or deflation." Robbins also attacked Keynes and his followers for endorsing the intermediate position of fixed but adjustable exchange rates.

However, because the British economic recovery occurred once the country had left the gold standard and the Bank of England was able to ease monetary conditions, other academic economists expressed some sympathy for the idea of floating exchange rates. For example, James Meade and Roy Harrod made positive statements about the merits of flexible rates but did not offer an unconditional endorsement.

Meanwhile, in comparison to their European counterparts, fewer American economists were wedded to the gold standard or even the goal of exchange rate stability. The dollar already played a central role in the international monetary system. From the American perspective, as 
long as the purchasing power of the dollar was relatively stable that would help promote the stability of the world economy. Many economists held a position similar to that of Keynes, believing that exchange rate stability was desirable but absolute rigidity was not. For example, as early as 1934, Harry Dexter White at the U.S. Treasury was writing in favor of a managed currency standard that would somehow combine the stability of the gold or dollar standard with national monetary autonomy. ${ }^{9}$

This position was widely held. John H. Williams of Harvard University and the Federal Reserve Bank of New York, one of the most prolific international economist of the period, wanted a compromise between the extremes of rigidly fixed exchange rates and completely flexible exchange rates. Williams $(1937,151)$ believed "there can be no general answer" to the question of whether fixed or flexible exchange rates were preferable and that it was "unduly simple" to pose the stark choice as "the difference between stable exchanges and stable prices, or as offering, or even compelling, a choice between external and internal monetary stability." At the same time, Williams $(1937,156)$ recognized that "the case for flexible exchange rates . . . has appeared to receive further powerful support from the world's experiences in the depression. Looking back, we have to recognize that recovery in every country where it has occurred has been accompanied by monetary expansion, and this expansion occurred after the internal economy had been freed from external pressure, either by currency depreciation or exchange control." And yet he noted that no government actually wanted to have flexible exchange rates. Therefore, Williams $(1937,163)$ advocated the compromise position of having the "largest measure of internal monetary protection and control which is consistent with exchange stability," with the proviso that "exchange variation, while not excluded, should be resorted to only when other means of control have been exhausted."

${ }^{9}$ Steil 2013, 22-23. 
By contrast, Frank Graham and Charles Whittlesey at Princeton University were among the few American economists who insisted that countries should have complete monetary independence and that flexible exchange rates were necessary to make such a system work. ${ }^{10}$ Graham and Whittlesey $(1934,401)$ stated that "unchanging exchange rates are one of the least important forms of stability and that they may give rise to more problems than they solve." They argued that no country should be asked to sacrifice internal stability for external stability since fixed exchange rates required that adjustment be achieved "through the painful and disrupting alternation of the whole [domestic] price structure, some parts of which are flexible and some parts rigid."

Graham and Whittlesey also took on the critics of flexible exchange rates. First, they argued that such rates were highly variable in the past because the underlying policies were highly variable. ${ }^{11}$ Whittlesey $(1937,66)$ asserted that economic history had been misinterpreted: "the view that stable exchange rates are a means of achieving stable general prices is grounded in a tendency to associate any freedom of the exchange rates with wild inflation. The fact that exchange movements under conditions of extreme inflation were much more result than cause is usually forgotten." Second, they suggested that speculative capital flows were not destabilizing if underlying policies were stable. Graham $(1940,27)$ argued that speculators would be deterred from betting against floating rates since future currency values were uncertain. By contrast, a fixed rate would be subject to speculative attacks since the direction of a future exchange rate change was known with greater certainty. Third, they argued that historical experience had demonstrated that the deleterious effect of exchange rate fluctuations on trade were "greatly

\footnotetext{
${ }^{10}$ See Endres (2008) for a more thorough discussion of Graham's advocacy of flexible exchange rates.

${ }^{11}$ Graham (1929) also made this point.
} 
exaggerated." In fact, futures markets could be used to protect those engaged in trade against unanticipated exchange rate movements.

Finally, Graham and Whittlesey dismissed the idea that fluctuating exchange rates would hamper the process of reducing trade barriers. Again, on the basis of historical experience, they argued that many import restrictions were imposed because of the payments imbalances that were the result of misaligned fixed exchange rates. Whittlesey $(1937,74)$ stated that import restrictions were "merely the logical consequence of the desire to maintain a quotation for the currency out of line with the equilibrium rate." Moving to an equilibrium exchange rate, as determined by the market, would allow trade barriers to be reduced. "Just as controls are introduced only because of a situation where the exchange rate is out of line with the equilibrium rate, so they become superfluous if the exchange rate is brought into an equilibrium position," Whittlesey $(1937,95)$ argued.

Thus, the collapse of the gold standard sparked a debate in which a broad spectrum of views about what type of international monetary regime ought to replace it. The consensus view was that exchange rate stability was desirable, although rates might have to be adjusted on occasion, whereas floating exchange rates would be unstable and therefore undesirable.

\section{The Debate over the 1943 Keynes and White Plans}

The U.S. and UK governments began making plans for the postwar international monetary system after the outbreak of World War II. In 1943, the White and Keynes proposals were published. While they differed on matters such as the structure of international lending facilities and the burden of adjustment between surplus and deficit countries, they did not differ significantly on the exchange rate regime itself. Both plans saw fixed exchange rates as 
desirable, while admitting that exchange rate changes would be necessary from time-to-time to correct for chronic payments imbalances. As Steil $(2013,150)$ notes:

"Both plans aimed at stability in exchange rates. However, Keynes's plan set up a mechanistic approach for determining when and by how much a member state could, or would have to, devalue or revalue, whereas White's plan was less accommodative of exchange rate changes, requiring member states to secure fund approval for any changes in parity. White's harder line on fixed exchange rates reflected American preoccupation with stopping others from devaluing against the dollar. On the flip side, Keynes's softer line reflected a British preoccupation with avoiding further bouts of a persistently overvalued pound." 12

While economists debated the various elements of the Keynes-White proposals, plans for a "fixed but adjustable" exchange rate system generated little controversy. Jacob Viner (1942, 129-30) of the University of Chicago noted that "economists are still divided on these issues, but I believe a large majority of them would agree that exchange stability is desirable per se, for any country and still more for the world at large, provided it can be established without involving helpless submission to undesired inflation or deflation.” John Williams $(1943,134)$ also applauded the compromise position - in which exchange rates would be fixed with "resort to currency variation only sparing and when other means had failed" - as one he had long championed. Furthermore, Williams noted that "among economists this debate over fixed versus flexible exchanges seems now to have almost entirely faded out, and to have been followed by a

\footnotetext{
${ }^{12}$ White $(1943,382)$ defended the plan saying "We cannot hope for sound recovery in international economic life so long as the germs of monetary instability infect a large part of the world. ... Only an intelligent adjustment of exchange rates to the new international economic position in the postwar period can provide a firm foundation on which to build a high level of world trade and prosperity."
} 
general recognition that international currency stability must be one of our main objectives for the post-war period."

By contrast, Graham (1943a, 401) was critical of the White-Keynes proposals on the grounds that it was easy to agree on fixed exchange rate parities but that no provision had been made on the underlying monetary policies to be pursued. "The international financial collapse of the early thirties is very largely attributable to the effort, in preceding years, to keep exchange rates fixed in a regime of divergent monetary policies," he argued. "But, in complete disregard of this evidence of the folly of seeking stable rates ... we seem bent on repeating the errors of the later thirties." Graham insisted that domestic price stability be given first priority and exchange rate stability was a secondary objective, if one at all. Graham $(1943 b, 22)$ was critical of the "quasi-official proposals of Lord Keynes and Dr. White" because they did "make a clean-cut choice of any of these alternatives." The problem with the Keynes-White plans is that "They straddle [the trilemma alternatives] and will either fall between stools or will issue in the comprehensive controls of foreign trade that it is the primary purpose of both authors to avoid."

Graham tried to defend flexible exchange rates on grounds of both theory and historical experience, but Ragnar Nurkse's influential League of Nations report, The Interwar Currency Experience, reinforced the dim view of the historical experience with flexible exchange rates and thereby gave indirect support for the White-Keynes plans. "If there is anything that interwar experience has clearly demonstrated," Nurkse $(1944,137)$ wrote, "it is that paper currency exchanges cannot be left free to fluctuate from day to day under the influence of market supply and demand." He warned that "if currencies are left free to fluctuate, 'speculation' in the widest sense is likely to play havoc" with them. To think that flexible exchange rates would help promote both external and internal stability was "quite unrealistic." Even with forward markets, 
exchange rate fluctuations would "inevitably tend to discourage international trade" and even result in "chaos."

Nurkse argued that flexible exchange rates had three serious disadvantages: they create an element of risk that discourages international trade, they create costly shifts of resources from traded to non-traded goods, and they cannot be relied on to promote adjustment. Hence, "stability of exchange rates has proved essential not only for international economic intercourse, but for domestic stability as well," pointing to France's experience in the $1920 \mathrm{~s}^{13}$ At the same time, absolute rigidity of exchange rates was also undesirable: "While exchange variations are certainly an unsuitable and undesirable means of dealing with short-term discrepancies in the balance of payments, an absolute rigidity of exchange rate in the face of drastic changes in other factors at home or abroad may thus be equally harmful," Nurkse $(1944,211)$ noted.

Nurkse's widely lauded book became the accepted view on the matter. Joan Robinson (1945, 406-07) commended him for producing "strong evidence to show that the notions of 'free' exchanges and of the 'automatic' gold standard are both equally chimerical. There is no escaping the fact that exchanges must be controlled by conscious policy." While "there are great advantages in exchange stability," Robinson also noted that Nurkse "brings forward strong evidence of the impossibility of a return to a system of completely rigid exchange rates," which once again supported the half-way house of fixed but adjustable rates.

\footnotetext{
${ }^{13}$ According to Nurkse (1944, 118ff): "The dangers of such cumulative and self-aggravating movements under a regime of freely fluctuating exchanges are clearly demonstrated by the French experience of 1922-26" when exchange rates became highly unstable and speculation rampant. "The experience of the French franc from 1922 to 1926 and of such interludes of uncontrolled fluctuation as occurred in certain currencies in the 'thirties demonstrates not only the difficulty of maintaining a freely floating exchange on an even keel, any movement in one direction being liable to create expectations of a further movement in that direction; it also shows how difficult it may be for a country's trade balance to adjust itself to wide and violent exchange variations." Subsequent economic historians have examined whether the French experience was one of destabilizing speculation or not. See also Tsiang (1959), Aliber (1962), Myhrman (1976), and Eichengreen (1982).
} 
Even Gottfried Haberler of Harvard University, a later advocate of flexible exchange rates, was at this point much more in tune with the Austrian tradition and rejected flexible rates. Haberler $(1945,309,311)$ wrote that "it is certain that a system of 'free exchanges' would lead to extremely undesirable results. It would incite capital flight and violent fluctuations. There are very few instances of really free exchanges in monetary history and none that could be called successful ... The upshot of this whole discussion is that a system of freely fluctuating exchanges is hardly acceptable." ${ }^{14}$

While Graham did not review Nurkse's book, Lloyd Mints of the University of Chicago was one of the few who rejected Nurkse's analysis. Mints (1945) wanted the monetary authority to pursue price stability and allow the exchange rate to seek its own level. ${ }^{15}$ Mints wondered why this option was not sought and questioned why there was a prejudice against flexible exchange rates. $^{16}$

\footnotetext{
${ }^{14} \mathrm{He}$ did concede that "if it were possible to prevent speculative capital movements, one of the most serious disadvantages of frequently changing exchange rates would be removed."

${ }^{15}$ Drawing from the experience of the 1930s, Mints $(1945,193)$ argued: "The essential thing is that the monetary agency of the government be not hamstrung in dealing with domestic deflation because of the loss of reserves. It would be far better if there is this danger simply to leave the gold standard, allowing the exchanges to seek their equilibrium level, and to increase the stock of currency to any level required to maintain the price level. This action would create no such restraint of trade as exchange rationing, and it does not involve a deliberate depreciation of the currency to which other nations may reasonably object."

${ }^{16}$ Mints argued that "This opposition seems to be founded in very large part upon a belief that the difficulties of the 1930's are inherent in any system of free exchanges. It is one thing to condemn, as one must, exchange fluctuations which are the consequence of widespread internal instability, and of consequent speculation in, and flights from, particular currencies; and it is quite a different thing to condemn, as one need not, such exchange fluctuations as would occur under conditions of internal stability. It is more than a little anomalous to condemn fluctuating exchange rates under conditions which a system of fixed exchanges could not survive. It is doubtful that fluctuating exchanges, under conditions of internal monetary stability, would create an undue discouragement to trade; or that they would be disequilibrating under the same conditions."
} 


\section{The Bretton Woods Agreement}

Given the agreement between White and Keynes on the matter, the "fixed but adjustable" exchange rate system was enshrined in the Bretton Woods system. While other provisions of the IMF on matters such as the burden of adjustment between surplus and deficit countries and the role of international reserves generated some debate at the Bretton Woods conference, there was almost no discussion about exchange rates. According to Article I of the IMF's Articles of Agreement, the goal of the system was "to promote exchange stability, to maintain orderly exchange arrangements among members, and to avoid competitive devaluation." In addition, "a member shall not propose a change in the par value of its currency except to correct a fundamental disequilibrium," a concept that was left undefined. ${ }^{17}$

After the 1944 conference, most economists thought the debate over exchange rate policy was settled. ${ }^{18}$ In a survey of work in international economics published shortly thereafter, Lloyd Metzler $(1948,223)$ noted that "from the point of view of economic analysis, one of the most important results of the experience with fluctuating exchange rates during the "thirties was a profound skepticism concerning the effectiveness of exchange-rate adjustments in rectifying a balance of payments discrepancy." Metzler $(1948,232)$ wrote that "both the interwar experience with fluctuating exchange rates and the theory of exchange stability which emerged during the interwar years have clearly shown that adjustments of exchange rates are not likely, in the short run, to be an efficient or effective means of eliminating a deficit or a surplus from a country's balance of payments."

\footnotetext{
${ }^{17}$ See Cesarano (2003).

${ }^{18}$ A paper in the American Economic Review stated, "the controversy a decade ago over fixed versus variable exchange rates, of little interest today, has been settled in favor of fixed rates with infrequent adjustments (Young 1947, 589).
} 
However, the transition to the new system did not go smoothly. In receiving a loan from the United States, Britain was required to make the pound convertible in 1947, which resulted in a massive run on the currency. Rather than devalue, Britain suspended convertibility (after spending much of the American loan in supporting its currency) and reimposed exchange controls. The pound had been overvalued, just as it had been in 1925 when the country returned to the gold standard, but this time instead of enduring deflation as a way of solving the trilemma the British authorities used exchange controls to insulate the economy from the pressure to deflate, although this restricted imports and created a shortage economy. Britain was not alone: the "dollar shortage" - the excess demand for dollars at the parity exchange rate - meant that many European countries were forced to rationing foreign exchange to restrain spending on imports if they were unwilling to adjust their exchange rate.

The dollar shortage also generated a large debate about whether import restrictions or devaluation would be the best way of achieving external balance. In Nurkse's view, exchange rate adjustment "far preferable" to import restrictions as means of ensuring external balance. Yet he was still skeptical of whether exchange rate changes would help achieve balance of payments equilibrium in the short-run. Therefore, Nurkse $(1947,574)$ continued to reject a regime of flexible exchange rates:

"Some liberal-minded economists are so impressed with the restrictive dangers of commercial policy that they would rather leave the maintenance of external equilibrium entirely to the care of fluctuations in exchange rates. This view may be attractive theoretically, but it places too much reliance on exchange-rate variations. Owing to the speculative tendencies which they provoke in commodity as well as capital flows, such variations are likely to be disruptive of internal stability. Experience has shown that the 
distinction between exchange stability and domestic stability may become quite unreal when exchange rates are left free to fluctuate under the influence of speculative anticipations creating excessive and 'nonfunctional' disturbances, not only in foreign trade, but also in domestic prices and production. This, at any rate, is apt to be the case when exchange variations are uncontrolled."

Meanwhile, Graham $(1949,21)$ called fixed rates "a vicious anachronism" and said that the objections to flexible rates were "largely sophistical." To Graham, the dollar shortage simply meant that the dollar was undervalued and European currencies were overvalued. Fixed rates increased speculation, as seen in the British case, because investors knew that existing rates were unsustainable. As Graham $(1949,18)$ noted: "We should know that we must either forgo fixed exchange rates or national monetary sovereignty if we are to avoid the disruption of equilibrium in freely conducted international trade or the systems of controls and inhibitions which is the only alternative when the internal values of independent currencies deviate - as they always tend to do - from what was, perhaps, a correct relationship when the fixed rates of exchange were set up."

British economists increasingly came to share this view. In particular, James Meade (1948) argued that maintaining unrealistically high and fixed exchange rates led to direct controls on import spending and posed an obstacle to the expansion of trade. In the choice between exchange rate adjustment and direct trade controls, he was decidedly in favor of the former. ${ }^{19}$ Posed this way, his view gained currency. "The idea that variations in foreign exchange-rates can serve as an efficient regulator of a freely working international economic

\footnotetext{
${ }^{19}$ Indeed, it becomes daily clearer that perhaps the main conflict in international economic policy - at least in so far as normal peace time arrangements are concerned - is the choice between quantitative controls and fluctuating exchange rates as the means of achieving and maintaining external balance. Those who seek for an extensive removal of trade barriers must logically work for fluctuating exchange rates. Meade $(1951,198)$.
} 
system has gained an astonishing vogue among British academic economists," Hubert Henderson $(1949,1,15,17)$ observed. "This, it is worth noting at the outset, implies a remarkable change of view. It is not very long since the extremists of economic liberalism were disposed to stress, and even to exaggerate, the advantages of fixed exchange-rates." Yet Henderson himself concluded: "The idea that exchange-rate variations might be used systematically to correct maladjustments in the balance of payments is ... fundamentally impracticable.”

The pressure on the system was final relieved when Britain announced a 30 percent devaluation of the pound in 1949, an action followed by nearly a dozen other countries. By this time, criticisms of the Bretton Woods approach were becoming more common. Robert Triffin ([1949] 1966, 182) complained that "the elaborate provisions of the Fund's agreement designed to ward off the danger of competitive devaluations were found powerless, and indeed somewhat paradoxical, in the face of the actual, and reverse, threat of currency overvaluation, propped up by quantitative restrictions, exchange controls, bilateralism and discrimination. ${ }^{20}$ Evidence accumulated that the emphasis on maintaining existing parities was making it difficult to remove trade and exchange controls. ${ }^{21}$

\footnotetext{
${ }^{20}$ Triffin ([1949] 1966, 180) noted: "Exchange stability, without substantial exchange freedom, is a meaningless objective to pursue. Our greatest danger is not competitive devaluation, but rather currency overvaluation buttressed by increasing controls, bilateralism, and discrimination. We must, therefore, facilitate rather than hamper exchange adjustments, insofar as they are conducive to an exchange ratepattern which will hasten the dismantlement of quantitative restrictions."

${ }^{21}$ Mints $(1953,55)$ was also critical of Bretton Woods tradeoff: "It seems evident that the American delegates to the Bretton Woods conference were chiefly interested in promoting multilateral trade, a consummation greatly to be desired, and that they believed stability of exchange rates would operate powerfully in this direction. While they by no means completely ignored the necessity of provide for international equilibrium, they nevertheless apparently either underestimated the importance of this problem or overestimated the efficacy of the very awkward means that the International Monetary Agreement provides. The result is that the government of the United States has been an important influence in support of the system of pegged exchange rates, and this system has compelled various nations to resort to direct controls of imports and bilateral agreements of precisely the kinds that the government of the United States was hopeful of avoiding."
} 
This was the context in which Milton Friedman visited Europe in 1950, where he drafted his famous essay "The Case for Flexible Exchange Rates," published in $1953 .^{22}$ The publication of Friedman's essay was followed by Friedrich Lutz's “The Case for Flexible Exchange Rates” in 1954 and Meade's “The Case for Variable Exchange Rates” in 1955. By this time, Canada had also adopted a flexible exchange rate and more and more economists were moving in the direction of supporting floating exchange rates. The debate over the exchange rate regime simmered for another two decades before the Bretton Woods system collapsed in the early 1970s.

\section{Conclusion}

While many features of the international monetary system were debated extensively prior to and during the 1944 Bretton Woods conference, there was surprisingly little debate among officials about the exchange rate regime. The preference for fixed exchange rates was derived in part from the consensus view that recent history had shown floating rates to have been a failure. A few economists disputed that history and warned that putting priority on fixed exchange rates might detract from other desirable policy objectives, such as domestic monetary autonomy and freer trade and capital flows. They criticized the Bretton Woods agreement for not confronting the dilemmas and trilemmas involved in reconstructing the international monetary system that eventually proved to play a role in its undoing.

\footnotetext{
${ }^{22}$ The debate over fixed and flexible exchange rates had been rejoined with Friedman's colleague, Lloyd Mints, devoting a chapter to his 1950 book Monetary Policy for a Competitive Society to "fixed versus flexible exchange rates." Mints $(1950,90)$ pointed out the "irreconcilable conflict between the requirements for international equilibrium and for domestic stability. . . This dilemma has long been recognized and many able writers have sought without success some way of escape from it." Boyer (2009) discusses the importance of Friedman's essay.
} 


\section{References}

Aliber, Robert Z. 1962. "Speculation in the Foreign Exchanges: The European Experience." Yale Economic Essays 2, 171-245.

Bordo, Michael D., and Anna J. Schwartz. 1996. "Why Clashes between Internal and External Stability Goals Result in Currency Crises.” Open Economies Review 7, 437-68.

Boyer, Russell. 2009. "Reflections on Milton Friedman's Contributions to Open Economy Money/Macro.” Journal of International Money and Finance 28, 1097-1116.

Cesarano, Filippo. 2003. 'Defining Fundamental Disequilibrium: Keynes' Unheeded Contribution.” Journal of Economic Studies 30, 474-492.

Cesarano, Filippo. 2006. Monetary Theory and Bretton Woods: The Construction of an International Monetary Order. New York: Cambridge University Press.

Eichengreen, Barry. 1992. Golden Fetters: The Gold Standard and the Great Depression, 19191939. New York: Oxford University Press.

Endres, Anthony, M. 2008. "Frank Graham's Case for Flexible Exchange Rates: A Doctrinal Perspective." History of Political Economy 40, 133-162.

Friedman, Milton. 1953. "The Case for Flexible Exchange Rates.” In Essays in Positive Economics. Chicago: University of Chicago Press.

Graham, Frank D. 1929. "Self-Limiting and Self-Inflammatory Movements in Exchange Rates: Germany." Quarterly Journal of Economics 43, 221-249.

Graham, Frank D. 1940. "Achilles' Heels in Monetary Standards.” American Economic Review 30, 16-32.

Graham, Frank D., and Charles R. Whittlesey. 1934. "Fluctuating Exchange Rates, Foreign Trade, and the Price Level." American Economic Review 24, 401-416.

Graham, Frank D. 1943a. "Discussion.” American Economic Review (Papers and Proceedings) 33, 332-335.

Graham, Frank D. 1943b. "Fundamentals of International Monetary Policy." Essays in International Finance No. 2. International Finance Section, Princeton University.

Graham, Frank D. 1949. "Exchange Rates: Bound or Free?” Journal of Finance 4, 13-27.

Graham, Frank D., and Charles R. Whittlesey. 1934. "Fluctuating Exchange Rates, Foreign Trade and the Price Level." American Economic Review 24, 401-416.

Haberler, Gottfried. 1945. "The Choice of Exchange Rates after the War." American Economic Review 35, 308-318. 
Hayek, Friedrich. 1937. Monetary Nationalism and International Stability. London: Longman, Green.

Henderson, Hubert. 1949. "The Function of Exchange Rates.” Oxford Economic Papers 1, 1-17.

Irwin, Douglas A. 2012. Trade Policy Disaster: Lessons from the 1930s. Cambridge: MIT Press.

Lester, Richard A. 1939. Monetary Experiments. Princeton: Princeton University Press.

Lutz, Friedrich A. 1954. "The Case for Flexible Exchange Rates.” Banca Nazionale del Lavoro Quarterly Review 7, 175-185.

Meade, James E. 1948. "Financial Policy and the Balance of Payments." Economica 15, 101115.

Meade, James E. 1955. “The Case for Variable Exchange Rates.” Three Banks Review

Moggridge, Donald E. 1986. "Keynes and the International Monetary System 1909-46." in International Monetary Problems and Supply Side Economics: Essays in Honour of Loris

Tarshis, edited by J. Cohen and G.C. Harcourt. London: Macmillan, 1986, 56-83.

Metzler, Lloyd. 1948. "The Theory of International Trade.” In A Survey of Contemporary Economics, edited by Howard S. Ellis. Philadelphia: Blakiston.

Mints, Lloyd. 1945. "Review of 'The International Currency Experience: Lessons of the InterWar Period." American Economic Review 35: 192-195.

Mints, Lloyd. 1950. Monetary Policy for a Competitive Economy. Chicago: University of Chicago Press.

Mitchner, Kris, and Kirsten Wadschneider. 2015. "Capital Controls and Recovery from Financial Crises: Evidence from the 1930s." Journal of International Economics 95, 188-201.

Myhrman, Johan. 1976. "Experiences of Flexible Exchange Rates in Earlier Periods: Theories, Evidence and a New View.” Scandinavian Journal of Economics 78, 169-196.

Nurkse, Ragnar. 1944. The International Currency Experience. Geneva: League of Nations.

Nurkse, Ragnar. 1947. "International Monetary Policy and the Search for Economic Stability." American Economic Review 37, 569-580.

Obstfeld, Maurice, Jay C. Shambaugh, and Alan M. Taylor. 2004. "Monetary Sovereignty, Exchange Rates, and Capital Controls: The Trilemma in the Interwar Period." IMF Staff Papers 51, 75-108.

Robbins, Lionel. 1937. Economic Planning and International Order. London: Macmillan.

Robinson, Joan. 1943. “The International Currency Proposals.” Economic Journal 53, 161-175 
Robinson, Joan. 1945. Review of "The International Currency Experience." Economic Journal $55,405-407$.

Steil, Benn. 2013. The Battle of Bretton Woods: John Maynard Keynes, Harry Dexter White, and the Making of a New World Order. Princeton: Princeton University Press.

Tsiang, S. C. 1959. "Fluctuating Exchange Rates in Countries with Relatively Stable Economies: Some European Experiences after World War I.” IMF Staff Papers 7, 244-273.

Viner, Jacob. 1942. “The International Economic Organization of the Future.” In Toward International Organization. New York: Harper \& Bros.

Viner, Jacob. 1943. "Two Plans for International Monetary Stabilization." Yale Review 33, 77107. Reprinted in Viner (1951).

Viner, Jacob. 1951. International Economics. Glencoe: Free Press.

Wandschneider, Kirsten. 2008. "The Stability of the Interwar Gold Standard: Did Politics Matter?” Journal of Economic History 68, 151-181.

White, Harry D. 1943. "Postwar Currency Stabilization.” American Economic Review 33, 382387.

Whittlesey, Charles R. 1937. International Monetary Issues. New York: McGraw-Hill.

Williams, John H. 1934. "The World's Monetary Dilemma: Internal versus External Monetary Stability." Proceedings of the Academy of Political Science 16: 62-68.

Williams, John H. 1937. "The Adequacy of Existing Currency Mechanisms under Varying Circumstances." American Economic Review 27, 151-168.

Williams, John H. 1943. "Problems of Post-War International Monetary Stabilization." Proceedings of the American Philosophical Society 87, 133-138.

Williams, John H. 1944. "Currency Stabilization: American and British Attitudes." Foreign Affairs 22: 233-247.

Wolf, Nicolas. 2008. "Scylla and Charybdis: Explaining Europe’s Exit from Gold, January 1928December 1936." Explorations in Economic History 45: 383-401. 